\title{
ALTHESIN AND THIOPENTONE: A CLINICAL COMPARISON
}

\author{
Jiri Obdrzalek
}

\section{INTRODUCTION}

DESPITE THE FACT that most anaesthetitsts tend to limit their choice to a few timehonoured drugs, the search for better anaesthetics has continued in an effort to extend the frontiers of our profession. In recent years a new ultra short-acting anaesthetic drug CT 1341 - "Althesin" - has been successfully introduced into clinical practice in Britain. ${ }^{1-4}$ Althesin is a mixture of two steroid compounds, alphaxalone and alphadalone acetate, dissolved in Cremophor E1. Anaesthesia is rapidly induced by intravenous injection of doses in excess of $0.05 \mathrm{ml} / \mathrm{kg}^{5,6}$ The drug has had a thorough experimental and clinical trial ${ }^{7,8}$ and in some respects would seem to be superior to the more commonly used thiopentone. The most valuable features of this new steroid anaesthetic are said to be rapid and smooth induction of anaesthesia, a wider therapeutic index, ${ }^{9,10}$ stability of the cardiovascular system ${ }^{1,11,12}$ and rapid and pleasant recovery. ${ }^{13-15}$ Althesin causes no tissue damage even in the case of accidental paravenous or intra-arterial injection ${ }^{9}$ and has been recommended as a safe induction agent or as the principal anaesthetic for short surgical procedures.

We have attempted to assess its usefulness and safety in the management of patients undergoing routine gynaecological operations. Many of these operations lasted less than fifteen minutes and this undoubtedly has limited the spectrum and accuracy of our measurements. In order to avoid the ever-present prejudice for or against a new drug, we conducted a double blind comparison of Althesin and thiopentone.

\section{Methods}

Althesin is a colourless liquid four times as potent as 2.5 per cent solution of sodium thiopentone volume for volume. It was diluted with normal saline to produce "volume equipotent" solutions. Diluted Althesin or 2.5 per cent thiopentone were drawn into $20 \mathrm{ml}$ syringes in random sequence and labelled by a reference number. The syringes were prepared each morning by the pharmacist and neither the anaesthetist nor the patients knew which drug was being used. The diluted solutions had comparable viscosities and a yellowish label masked the difference in colour.

The study was conducted on 200 consecutive patients scheduled for routine gynaecological operations. Pregnant women or those with suspected sensitivity to thiopentone or halothane were excluded. Premedication was deliberately avoided. Informed consent was obtained from each patient prior to the induction of anaesthesia and an intravenous infusion of lactated Ringer's solution was started.

"Department of Anaesthesia, St. Michael's Hospital and University of Toronto. 
The anaesthetic was injected from a coded syringe in a dose of $0.2 \mathrm{ml} / \mathrm{kg}$ body weight or until consciousness was lost. This was established by loss of response to verbal stimuli and by loss of the eyelash reflex. For minor operations the patients were allowed to breathe 66 per cent nitrous oxide in oxygen from a semiclosed anaesthetic circuit. The anaesthetic was maintained by intermittent injections of several millilitres of the coded drug. For longer or abdominal operations anaesthesia was maintained using 0.5 to 1 per cent halothane and d-tubocurare with mechanical ventilation through a tracheal tube.

Blood pressure, pulse rate, respiratory rate and minute volume were measured before induction and at five-minute intervals during the operation. At the conclusion of the operation, 100 per cent oxygen was substituted for the nitrous oxide mixture and recovery time was measured. The recovery was evaluated by the ability of the patient to open her eyes and respond to verbal commands. Patients were examined again by the anaesthetist prior to their discharge from the recovery room.

After the trial had been completed, the pharmacist divided all patients into two groups. Groups were compared by Student's $t$ test for numerical values and by probability distribution for binomial indices. Once the statistical calculations had been completed, groups were identified, but this was hardly necessary as the differences between the two groups were striking.

\section{Results}

Ninety patients received Althesin and 100 thiopentone. Ten patients were excluded from the study because of incomplete records. In the patients in whom anaesthesia had been maintained with halothane and d-tubocurare, only the measurements prior to administration of halothane are included.

Table I indicates that the groups were comparable in size, age, weight and clinical status as well as in the extent of the operative procedures. The mean induction dose and the maintenance doses in terms of volume as well as the duration of operation were also quite similar.

TABLE I

\begin{tabular}{|c|c|c|c|c|}
\hline & & Althesin & Thiopentone & $\Delta$ \\
\hline $\begin{array}{l}\text { Number of patients } \\
\text { Age } \\
\text { Weight } \\
\text { Induction dose* } \\
\text { Maintenance dose* } \\
\text { Operating timet } \\
\text { Minor operations } \\
\text { Abdominal operations } \\
\text { Anaesth. status } 1 \\
2 \\
3 \\
4\end{array}$ & $\begin{array}{l}\text { years } \\
\mathrm{Kg} \\
\mathrm{ml} / \mathrm{kg} \\
\mathrm{ml} / \mathrm{kg} / \mathrm{min} \\
\mathrm{min} \\
\% \\
\% \\
\% \\
\% \\
\% \\
\% \\
\%\end{array}$ & $\begin{array}{r}90 \\
34.5 \\
59.3 \\
5.0 \\
13.0 \\
12.1 \\
66 \\
24 \\
73 \\
27 \\
0 \\
0\end{array}$ & $\begin{array}{r}100 \\
36.9 \\
61.0 \\
5.0 \\
13.0 \\
13.2 \\
78 \\
22 \\
69 \\
37 \\
0 \\
0\end{array}$ & $\begin{array}{l}\mathrm{NS} \\
\mathrm{NS} \\
\mathrm{NS} \\
\mathrm{NS} \\
\mathrm{NS} \\
\mathrm{NS} \\
\mathrm{NS} \\
\mathrm{NS} \\
\mathrm{NS}\end{array}$ \\
\hline
\end{tabular}

*Diluted Althesin, 2.5 per cent solution of thiopentone.

$\dagger$ Abdominal operations under halothane are excluded.

$\Delta$ Difference between groups: NS = not significant, $\dot{S}=$ significant at 5 per cent. 
TABLE II

\begin{tabular}{|c|c|c|c|}
\hline & Althesin & Thiopentone & $\Delta$ \\
\hline \multirow{2}{*}{ Mydriasis } & $\%$ & $\begin{array}{l}\% \\
17\end{array}$ & \\
\hline & $\begin{array}{l}79 \\
22\end{array}$ & 17 & $\stackrel{S}{S}$ \\
\hline Excitement on induction & 16 & 8 & $\begin{array}{l}S \\
S\end{array}$ \\
\hline Halothane supplement & 16 & 2 & $\overrightarrow{\mathrm{S}}$ \\
\hline Hypertension $+30 \mathrm{mmHg}$ & 12 & 4 & $\mathrm{~S}$ \\
\hline Hypotension & 1 & 7 & $\mathrm{~S}$ \\
\hline+30 beats $/ \mathrm{min}$ & 3 & 3 & NS \\
\hline-30 beats $/ \mathrm{min}$ & 0 & 2 & NS \\
\hline$+20 \mathrm{resp} / \mathrm{min}$ & 23 & 1 & $\mathrm{~s}$ \\
\hline$-10 \mathrm{resp} / \mathrm{min}$ & 0 & 1 & NS \\
\hline Hyperventilation & 55 & $3 \overline{6}$ & $\mathrm{~S}$ \\
\hline Hypoventilation & 1 & 1 & NS \\
\hline Obstruction & 15 & 27 & NS \\
\hline Cough & 27 & 13 & $\mathrm{~S}$ \\
\hline Laryngospasm & 3 & 6 & NS \\
\hline Vomiting & 10 & 13 & NS \\
\hline Necklace flush & 13 & 9 & NS \\
\hline Disturbing movements & 37 & 25 & NS \\
\hline Rapid recovery $\quad<1.0 \mathrm{~min}$ & 69 & 16 & $\mathrm{~S}$ \\
\hline Prolonged recovery $>10.0 \mathrm{~min}$ & 6 & 37 & $\underset{S}{S}$ \\
\hline Hangover & 22 & 82 & S \\
\hline Dysphoria & $\begin{array}{l}3 \\
4\end{array}$ & $\begin{array}{l}8 \\
4\end{array}$ & $\begin{array}{l}\text { NS } \\
\text { NS }\end{array}$ \\
\hline $\begin{array}{l}\text { Euphoria } \\
\text { "Excellent" anaesthesia }\end{array}$ & $\begin{array}{r}4 \\
14\end{array}$ & $\begin{array}{l}4 \\
1\end{array}$ & $\mathrm{~S}$ \\
\hline "Poor" anaesthesia & 27 & 22 & NS \\
\hline
\end{tabular}

The results are summarized in Table II. One of the most consistent findings in the Althesin group was the considerable and persistent dilatation of pupils, present in 79 per cent of the cases. The patients receiving thiopentone usually had constricted pupils, although transient dilatation was occasionally found during induction. The pupils returned to normal size within minutes after conclusion of anaesthesia.

Another common feature of anaesthesia with Althesin was a fine tremor of the eyelids during induction. Although it was seen in only 22 per cent of Althesin cases, it was never seen when thiopentone was used. Spontaneous movements of the extremities were seen with both anaesthetics, but were both more frequent and more vigorous when Althesin was used. Cough and hiccup were also seen more frequently with Althesin. Whereas the higher doses of thiopentone readily suppressed this type of activity, higher doses of Althesin were less effective and addition of halothane was needed in 16 per cent of these cases.

Both agents showed remarkable stability of the cardiovascular system. The pulse rate remained unchanged and swings of blood pressure were rare despite considerable surgical stimulation. Several instances of hypertension were seen with Althesin and in contrast 7 per cent of the patients receiving thiopentone became slightly hypotensive. Apnoea up to 40 seconds was seen frequently in both groups. Whereas respiratory rates remained stable with thiopentone surgical stimulation produced considerable tachypnoea in 23 per cent of the patients receiving Althesin. Apart from short apnoea on induction, true respiratory depression was never 
observed. Airway obstruction necessitating the insertion of an oropharyngeal airway occurred in 15 per cent of the patients in the Althesin group as against 27 per cent for thiopentone. Laryngospasm was seen more often after thiopentone than after Althesin. Ten per cent of patients vomited on recovery from Althesin as against 13 per cent after thiopentone. None aspirated. Thiopentone induced moderate bronchospasm in two patients. One case of local erythema and one case of phlebitis were seen in the thiopentone group. No tissue reaction was seen with Althesin. Flushing of the face and neck was frequently observed shortly after the injection of either drug. This was never associated with a change in blood pressure or with bronchospasm.

Withdrawal movements were more frequent and more vigorous in the Althesin group. This was the only real problem throughout the whole study and even high maintenance doses did not prevent it.

The striking difference between the two drugs was apparent during recovery. Almost 70 per cent of the Althesin patients opened their eyes within one minute after the procedure and were able to converse intelligently within the next one to two minutes. The patients were remarkably clearheaded so that the recovery-room staff frequently thought the operation had been done under epidural anaesthesia. In contrast, mean recovery time in the thiopentone group was 10.9 minutes and 87 per cent of these patients had a "hangover" or appeared sleepy when examined 30 minutes after the termination of the anaesthetic. Confusion and hysterical reactions, although uncommon, were observed more often in the thiopentone group.

"Excellent" anaesthesia, characterized by smooth induction, peaceful maintenance and rapid and pleasant recovery was achieved in 14 per cent of the patients receiving Althesin and 1 per cent of the patients receiving thiopentone. No problems were seen when either drug was used for induction only. Our overall impression was that the drugs were equally good when used for induction of anaesthesia. Thiopentone was slightly superior to Althesin for maintenance. In respect to recovery, Althesin appears to be far superior to thiopentone.

\section{Discussion}

The cornerstone for a fair comparison is the decision regarding the relative potency of the two drugs. Since every drug produces a variety of responses in the body, doses can be graded as equipotent in respect to one specific effect, but at the same time these doses are not necessarily equipotent in respect to other effects. The equipotent dose in our study was defined as a quantity of the drug which would just induce an anaesthetic state. In this respect $0.05 \mathrm{ml} / \mathrm{kg}$ of (undiluted) Althesin and $5 \mathrm{ml} / \mathrm{kg}$ of thiopentone were assumed to be equally potent. However, since the slope of the dose-response curve is steeper for thiopentone than for Althesin, ${ }^{6,9.10}$ higher doses of Althesin will be less effective than higher doses of thiopentone. This is the basis for the wider therapeutic index, i.e. the wider safety margin of Althesin. This may also account for the difficulty to suppress laryngospasm, cough or movements by small additional doses of Althesin. Another factor which may further potentiate the "flatness" of the dose-response curve is 
the rapid metabolic degradation of Althesin. Whereas thiopentone accumulates insidiously in the body (especially if supplemental doses are used over a prolonged period of time) Althesin is rapidly cleared by the liver, ${ }^{9,16.17}$ This almost certainly accounts for the rapid recovery and absence of hangover, but at the same time may be a limiting factor when reinforcement of the anaesthetic is required. The problem is well illustrated by one surgeon's remark: "No wonder the patients recover fast after Althesin - they were never asleep in the first place." Perhaps higher supplemental doses of Althesin should have been used; however, the main advantage of rapid recovery might then have been lost. From the high incidence of disturbing movements, cough and laryngospasm it is obvious that both drugs are far from "ideal" when used as principal anaesthetics even for short procedures. It is certainly true that many problems would be avoided if these anaesthetics were supplemented by premedication, volatile agents, or by small doses of a narcotic. But then again, recovery from anaesthesia probably would be prolonged. When either drug was used for induction of anaesthesia only, no complications were observed. Althesin appears to be an excellent induction agent, closely comparable to thiopentone. The cardiovascular stability seen in our patients in both groups was to a certain extent surprising. It should be kept in mind that our patients were relatively young and healthy and caution is suggested when cardiovascular reserve is limited, ${ }^{18-20}$

\section{SUMMARY}

Althesin was compared with thiopentone in a double blind study of 200 patients undergoing gynaecological operations. Althesin in a dose of $0.05 \mathrm{ml} / \mathrm{kg}$ was found to be an excellent induction agent, virtually devoid of undesirable side effects; however, when used as the principal anaesthetic (supplemented only by 66 per cent nitrous oxide in oxygen), the incidence of disturbing movements was high. Recovery time from Althesin was one-third of that after thiopentone. The patients recovering from Althesin were remarkably clearheaded with a low incidence of "hangover".

\section{RÉSUMÉ}

L'althesin a été comparé au thiopentone dans une étude à double-insu chez 200 patientes subissant une intervention gynécologique. L'althesin, à des doses de 0.05 $\mathrm{ml} / \mathrm{kg}$ s'est avéré être un excellent agent d'induction, pratiquement sans effet secondaire indésirable; cependant, lorsqu'il était employé comme agent anesthésique principal (avec $\mathrm{N}_{2} \mathrm{O} 66$ pour cent et oxygène), l'incidence de mouvements ennuyeux était élevée. Le temps d'éveil après emploi d'althesin était du tiers de celui du thiopentone. Les patients étaient beaucoup plus lucides à l'éveil avec une incidence de "hangover" minime.

\section{ACKNOWLEDGMENTS}

The study was supported by a grant from Glaxo Canada Ltd. The author wishes to thank the pharmacists, Mrs. M. Chambers, Mrs. P. Wagner and Mrs. S. Halasi and also Drs. S. Eeson and W. Gallacher for their support and efficient help. 


\section{REFERENCES}

1. Campeell, D., Forrester, A.C., Miller, D.C., Hutton, I., Kennedy, J.A., Lawrie, T.D.V., Lorrimer, A.R., \& MCCALL, D. A preliminary clinical study of CT 134l. Brit. J. Anaesth. 43: 14 (1971).

2. Clarke, R.S.J., Montgomeny, S.J., Dundee, J.W., \& Bovill, J.G. Clinical studies if induction agents XXXIX: CT 1341, a new steroid anaesthetic. Brit. J. Anaesth. 43: 947 (1971).

3. Swerdlow, M., Chakraborty, S.K., \& Zahangir, M.A.H.M. A trial of CT 1341. Brit. J. Anaesth. 43: 1075 (1971).

4. Savege, T.M., Foley, E.I., Coultas, R.J., Walton, B., Sthunin, L., Simpson, B.R., \& Scotr, D.F. CT 1341: some effects in man. Cardiorespiratory, electroencephalographic and biochemical measurements. Brit. J. Anaesth. 26: 402 (1971).

5. Clarke, R.S.J., Dundee, J.W., \& Carson, I.W. Some aspects of the clinical pharmacology of Althesin. Postgrad. Med. J. Suppl. 2, 48: 62 (1972).

6. Tammisto, T., TAKKI, S., Tigerstedt, I., \& Kauste, A. A comparison of Althesin and Thiopentone in induction of anaesthesia. Brit. J. Anaesth. 45: 100 (1973).

7. Symposium on steroid anaesthesia. Postgrad. Med. J. Suppl. 2, 48: 9-139 (1972).

8. Glaxo Canada Ltd. Althesin (CT 1341) information for investigators.

9. Davis, B. \& Pearce, D.R. An introduction to Althesin (CT 1341). Postgrad. Med. J. Suppl. 2, 48: 13 (1972).

10. Child, K.J., Currie, J.P., Davis, B., Dodds, M.G., Pearce, D.R., Twissell, D.J. The pharmacological properties in animals of CT 1341 - a new steroid anaesthetic agent. Brit. J. Anaesth. 43: 2 (1971).

11. Prys-Roberts, C., Fö̈x, P., \& Bıro, G.P. Cardiovascular responses of hypertensive patients to inductiin of anaesthesia with Althesin (CT 1341). Postgrad. Med. J. Suppl. 2, 48: 80 (1972).

12. Savege, T.M., Foley, E.I., Ross, L., \& Maxwell, M.P. A comparison of the cardiorespiratory effects during induction of anaesthesia of Althesin (CT 1341) with thiopentone and methohexitone. Postgrad. Med. J. Suppl. 2, 48; 66 (1972).

13. Hannington-Kiff, J.G. Comparative recovery rates following inductiin of anaesthesia with Althesin and methohexitone in out-patients. Postgrad. Med. J. Suppl. 2, 48: 116 (1972).

14. Warren, J.B. Althesin in the dental chair. Postgrad. Med. J. Suppl. 2, $48: 130$ (1972).

15. Swendow, M. Studies with Althesin - a new steroid anaesthetic. Postgrad. Med. J. Suppl. 2, 48: 105 (1972).

16. Cafd, B., McCulloch, R.J., \& Pratt, D.A.H. Tissue distribution of CT 1341 in the rat; an autoradiographic study. Postgrad. Med. J. Suppl. 2, 48: 34 (1972).

17. Child, K.J., Gibson, W., Harnby, G., \& Hart, J.W. Metabolism and excretiin of CT 1341 (Althesin) in the rat. Postgrad. Med. J. Suppl. 2, 48: 37 (1972).

18. Gordr, T. The effect of Althesin on the heart in situ in the cat. Postgrad. Med. J. Suppl. 2, 48: 31 (1972).

19. Foёx, P.\& Prys-Roвerts, C. Pulmonary haemodynamics and myocardial effects of Althesin in the goat. Postgrad. Med. J. Suppl. 2, 48: 24 (1972).

20. Miller, D.C., Bradfond, E.M.W., \& Camprell, D. Haemodynamic effects of Althesin in poor-risk patients. Postgrad. Med. J. Suppl. 48: 133 (1972).

21. Harrison, S.G.C. \& Sellick, B.A. Cardiovascular effects of Althesin in patients with cardiac pathology. Preliminary communication. Brit. J. Anaesth. 44: 1205 (1972). 